\title{
Fundamentalism and the Internet
}

\author{
Rüdiger Lohlker
}

This study is an analysis of the interrelation of fundamentalism and the Internet. Contrary to common assumptions that the Internet is a space of free communication and construction of individuality - and contrary to the assumption of total control - the internal structure of the Web is understood as creating a space structured by hierarchical structures fundamentalist internet use positively accepts. Two case studies look into the role of fundamentalist video practices on the Web exemplified by Salafist and Hindutva internet activities.

Rüdiger Lohlker is professor for Islamic Studies at the University of Vienna (2003-), head of a trainings course for Imams and mosque activists, University of Vienna (2010-). He taught at the universities of Giessen, Göttingen, and Kiel, and worked, e.g., at the Bibliothèque Générale et Archives (Rabat, Morocco). His research areas are history of Islamic thought, Islamic law, modern Islamic movements, Islam and the Arab world online, Jihadism, Salafism.

\section{Introduction}

The still persistent idea the Internet may be a force that encourages democratic developments just because it exists betrays its origin going back to the ,good old time" of the virtual community of Howard Rheingold (1993) in the beginnings of the Internet, still based on Bulletin Board Systems, Usenet groups, etc.

We might say the Arab Uprisings tell us this assumption may be true. But looking at the uprisings after the fog of media uproar - and the usual somewhat delayed academic reaction - lifted we may tell another story. The so-called Facebook, Twitter, YouTube revolutions were revolutions that used all media available (see Najar 2013) but were successful physically in the public space (see, e. g., Dabashi 2012; Achcar 2013). Remember Tahrir place in Egypt or the Pearl place in Bahrain! The tragedy of the Syrian people and the emergence of the professional Internet or cyber warfare by entities like IS (Islamic State) demonstrate that there is no democratic DNA built into online platforms - leaving aside the mere fact we are talking about business companies that should be profitable.

So it is not surprising that fundamentalist movements, groups, and individuals are successfully active online since there is no intrinsic democratic character of the Web. It is not a case of "divided modernity" (Tibi 1985) - one part exploited by fundamentalists, the technical one, and the other part, the democratic, enlight- 
ened one, ignored by them -, an idea that shows a normative misunderstanding of technology as a mere tool to be used.

This does not mean I neglect the influence of the "mentalité technique" (Simondon 2006) on our perception of the world. I would rather like to introduce the idea of the agency of technology (e. g., Latour 2005; Harman 2009) into the discussion of fundamentalism and the Internet. The role of technology can be understood as part of a network of actors including humans and technological devices that may not be divided into isolated entities but related to each other.

Coming back to the question if the Internet can be regarded as a space of freedom, Eugene Thacker wrote in the foreword to Alexander R. Galloway Protocol (2004, pp. XIII-XIV) (!) on code, protocol, and networks:

Further, code is not necessarily language, and certainly not a sign. A code, in the sense that Protocol defines it, is process-based: It is parsed, compiled, procedural or objectoriented, and defined by ontology standards. A code is a series of activated mechanical gears, or a stack of punched cards circulating through a tape-reading machine, or a flow of light-pulses or bits in a transistor or on silicon, or a vat of binding interactions between DNA fragments.

When the book suggests that networks are not metaphors (or not merely metaphors), the dichotomy is not one between material and immaterial, but rather between two types of "abstract". On the one hand, there is an abstract use of the concept of networks generally to signify any relationship between discrete entities. According to this usage, just about anything can be seen as a network (and thus the overwhelmingly wide application of certain network science or complexity approaches). But there is also another meaning of "abstract", one that is not the opposite of concrete. An abstract that is real is a potential. (Henri Bergson uses the term "virtual" for the immanent unfolding of duration as potentiality.) This is not the abstract use of network as a term, and neither is it an abstraction of a technical term (the metaphorization of technological terms). Rather, this abstract-but-real is the network that is always enacted and always about to enact itself. One can pose the question: Is a network a network if it is not being used? Is the Internet a network because of its fiber-optic cables, its usage, its data transfer, the standards for such use, or the concepts that inform the development of network technology itself? Likely all of these (Galloway 2004, pp. XIII-XIV).

But there is more to networks. Following these early insights again we should turn to the protocols governing the Web:

If, in the discourses surrounding networks, the tropes of connectivity, collectivity, and participation obscure the material practices of networks, Protocol points to several principles for understanding networks as "a diagram, a technology, and a management style". To begin with, general talk about "networks", dissociated from their context and technical instantiation, can be replaced by a discussion of "protocols". Every network is a network because it is constituted by a protocol. If networks display any of the tropes mentioned above, it is because there is an infrastructure that enables such properties to emerge. Not networks, but protocols. Given this, Protocol can be read as a book of 
political economy. It argues for a methodological shift from a generalized understanding of networks to a specified one, in which the protocological systems of TCP/IP and DNS operate as what Foucault termed "political technologies" (Galloway 2004, p. XVIII).

These political technologies ensure control and management of networks, the Internet in general. So - as we stated before - there is no intrinsic democratic value of the Web if we do not believe in the marketing hype of social media or Web 2.0 , both concepts invented for marketing purposes, or participation and sharing, etc. - just the same.

Turning to the users who use the network and by being a user enact the network as mentioned above, our positive view of the Web and social media may be disturbed again. Geert Lovink wrote about the nihilistic, self-centered worldview expressed by bloggers some years ago (Lovink 2008). Although that's not the full story of blogging from a global point of view, reflecting a European/North American experience rather, there is something true about it. Blogs and social media are first of all an instrument to present yourself, your worldviews to an audience listening to you and your elaborations.

The new forms of digital communication are shaped by a specific form of individuality (Reichert 2008) it is said. I would like to say subjectivity instead of individuality since users are better understood as subjected to technical and social domination. Studies focusing on the "sovereignty of the individual spiritual consumer" (Houtman / Aupers 2010, p. 7) tend to overlook these structures of power. There are technical constraints: Users take these constraints for granted, e.g., using 140 signs to express - not yourself! - but to put your communication online on Twitter to give a very basic example.

But there are also social constraints - or to be more moderate: contexts. To move away from the academic practice of privileging written ideas or anything printed, we should remind us:

Social media sites are full of:

- Demographic information;

- Lists of friends, family, and associates;

- Logs of activities, preferences, and favorites;

- Maps showing places a person goes and how frequently;

- Time-stamped posts that indicate where a person was and when; and

- The content of the posts themselves, where people detail their thoughts, feelings, and ideas (Golbeck 2015, p. 1; see also Golbeck 2015).

So when talking about social media, we are talking about many things. But I will restrict my argument to the last three elements of the list: "thoughts, feelings, and ideas". Social media gave birth to a new media culture of practices of the selfincluding guiding yourself, confession, book-keeping and a very precise form of 
benchmarking your performance, an experimental way of relating to yourself and an esthetic of self-staging.

Social media sites provide an ambiance for new practices of subjectivity, creating new forms of centering on the self and new relations of power. Social media expect the willingness of the user to give away more and more data and information to open for them a window of participation. The user has to be willing to submit to the new regime of visibility. This means to accept the need to learn the ever new forms of self-expression, to master these forms, and - on an advanced level - to refine these forms.

The most recent form of this way self-staging may be the hype of selfies (Reichert 2015). We may assume it will slowly fade away due to the fact it has been appropriated by Barack Obama et al., an act killing all forms of youth protest and self-styling. But there is still another way of self-styling not referring to age groups, professional groups or social strata. It is part of larger realm of "digital religion" (Hoover / Echchaibi 2014) that can be compared to the emergence of religion in the context of older new technologies:

A prodigious scholarly and lay discourse has developed since at least the mid-1990s focused on the ways that emergent digital technologies and practices might have implications for religion and the meaning of "the religious". From the beginning, much of this speculation focused on the capacities of technologies to substitute for or compete with received and known valences of religion. In this way, it was not that different from the prior emergence of the mediated broadcast religion we now know as "televangelism". In that case as well, most commentary (both popular and scholarly) focused on how this emergent phenomenon - and one that was brought about a "new technology" of the time - (cable television) might have implications religion and its legitimated structures, contexts, and practices. It was difficult for observers to think about that new mediation of religion outside received categories, terms, definitions, and metaphors. With the benefit of hindsight, we can now see that televangelism was not just "about" substituting for prior practice. It was more profoundly a re-making of the expectations, meanings and contexts through which religion is not only transmitted, received, shared and practiced but also about new generativities, new forms of "the religious", and their extents and boundaries. Televangelism itself was not the point. It opened the door to re-imagining where religion might be produced and by whom (Hoover / Echchaibi 2014, p. 2).

We may join Hoover / Echchaibi in their question:

[I]t became obvious to us that much could be gained in our understanding by re-centering our focus on "the religious digital" (thus broadly defined), its attributes, extents, and limits. Rather than assuming received categories of religion, spirituality, or religious or spiritual politics, or received physical or cultural geographies (the local/global dualism an example of the former, and gender politics an example of the latter) what might we learn by assuming that in digital religion we were looking at something on its own terms and its own locations? (Hoover / Echchaibi 2014, p. 5). 
So we are talking about digital religion:

Digital religion is religion that is constituted in new ways through digital media and cultures. Hoover highlights that this may lead to a new understanding of religion, one that is rooted in unique understandings and experiences of mediation of meaning via digital technology. This recognizes that the reformulation of existing religious practices has both online and offline implications. It also means digital culture negotiates our understandings of religious practice in ways that can lead to new experiences, authenticity, and spiritual reflexivity. Based on this I suggest that the term "digital religion" describes the technological and cultural space that is evoked when we talk about how online and offline religious spheres have become blended or integrated. We can think of digital religion as a bridge that connects and extends online religious practices and spaces into offline religious contexts, and vice versa. This merging of new and established notions of religious practice means digital religion is imprinted by both the traits of online culture (such as interactivity, convergence, and audience-generated content) and traditional religion (such as patterns of belief and ritual tied to historically grounded communities) (Campbell 2013, pp. 3 f.).

Fundamentalist movements active on the Web are a particular form of digital religion. We will look into fundamentalism online by focusing on videos. There are other areas of research on online fundamentalism, e.g., the use of memes (see Bellar et al. 2013), but still videos seem to be the most influential online practice of fundamentalists.

\section{Fundamentalism}

To give a kind of definition, I would like to turn to Martin Riesebrodt (see Riesebrodt 2005). He stated that contrary to the widespread view that fundamentalists are pursuing political aims we may insist on the fact that most fundamentalist groups organize themselves as subcultures or a kind of communal organizations separating itself symbolically or in space from other groups or cultural milieus. These communal organizations and subcultures try to create circumstances allowing them to follow their lifestyle without any restrictions and to educate the following generations. So in most cases the shaping of subjectivity through a pious way of living the cultivation of a specific religious ethos is at the center of fundamentalist activity.

\section{Piety Movement in Egypt}

For a case study we may look at the piety movement of women in Egypt from the 1980s onward: 
According to participants, the mosque movement had emerged in response to the perception that religious knowledge, as a means of organizing daily conduct, had become increasingly marginalized under modem structures of secular governance. The movement's participants usually describe the impact of this trend on Egyptian society as "secularization" ('almana or 'almāniyya) or "westernization" (tagharrub), a historical process which they argue has reduced Islamic knowledge (both as a mode of conduct and a set of principles) to an abstract system of beliefs that has no direct bearing on the practicalities of daily living. In response, the women's mosque movement seeks to educate ordinary Muslims in those virtues, ethical capacities, and forms of reasoning that participants perceive to have become either unavailable or irrelevant to the lives of ordinary Muslims. Practically, this means instructing Muslims not only in the proper performance of religious duties and acts of worship but, more importantly, in how to organize their daily conduct in accord with principles of Islamic piety and virtuous behavior.

Despite its focus on issues of piety, it would be wrong to characterize the women's mosque movement as an abandonment of politics (see Mahmood 2005, p. 4).

To rephrase the approach of Riesebrodt, we may say that fundamentalism is a way of organizing itself as subcultures or communal organizations having political implications for the society at large. Turning to fundamentalism and the media we may look into

Charles Hirschkinds of pre-Tahrir Cairo The Ethical Landscape. It is not an account of ideas and beliefs, but an analysis of exchanges that belong to a particular way of life. He asks how the enormously popular practice of listening to sermons in Cairo shaped religious sensibilities [...] Throughout Islamic history attending the Friday sermon has been an important part of - male - Muslim subject formation. Hirschkind analyzed the reception of sermons as an active process, one in which the faithful listener cultivated his or her ability to attend. Listening to sermons in modern Cairo is no longer confined to the Friday mosque and it is no longer a one-off experience. Taped sermons can now be heard numerous times, in many urban contexts, without supervision. Hirschkind describes this with the felicitous phrase "undisciplined discipline" (Asad 2012, pp. 54 f.).

Hirschkind's accounts of the pious movements in Egypt describes how the practice of cassette listening promoted an acoustic sensibility opposed to the former state's obsession with spatial control, as well as to the nouveaux riches who had withdrawn in their clean, orderly gated communities. Contained in this opposition was an unending struggle for how "real Islam" is to be lived. What Hirschkind calls a "counter-public" is thus an Islamic space of moral distancing from the hegemonic religious-secular order. Many Islamists, he tells us, regarded the regime of discipline as helping to develop a responsiveness that might moderate, if not totally negate, the seductions of neoliberal consumer culture (see Asad 2012, p. 55). 
So we may look at fundamentalist, pious subcultures and groups as entities creating new forms of subjectivity creating the community again and again by perpetuating the fundamentalist ethos and using modern media, in his case study audiocassettes, CDs; we now may find DVDs or Blue Ray discs.

What makes the Internet especially fit for these purposes is the general structure of Internet practice as management of the self and the general "undisciplined discipline" of the users. Practicing this undisciplined discipline may include attending prayer groups, reading circles, etc. but using the platforms of the Web enables the new fundamentalist subjects to subject themselves to the discipline of the fundamentalist protocol in the guise of freely choosing - individually - between what is available on the fundamentalist media market. This ability to choose marks the modernity of fundamentalism.

One new fundamentalist set of movements emerging from the Islamic piety movements of the 1970s and 1980s referred to before is Salafism. Salafists have been very active in appropriating the new media, esp. satellite TV and the Internet. A paradigmatic case is a German Salafi group running the site diewahrereligion.org.

\section{Salafism}

Salafism in Germany (influencing Austria, too) have attracted some interest in the last years motivated by security concerns. Several studies tried to analyze this phenomenon (Schneiders 2014, Ceylan / Jokisch 2014, Said / Fouad 2014). We will focus on the website mentioned above. The group running this site is known for the campaign of distributing copies of a German translation of the Quran in Germany, Austria, and Switzerland. It is slowly internationalizing distributing, e.g., in Sweden (https://www.facebook.com/diewahrereligion; January 9, 2016, in Malmö).

The site is linked to an active Facebook account and a YouTube channel (https://www.youtube.com/user/Allahsreligion/) offering many videos. Central to all these sites is the campaign of distributing free copies of the Quran. The older version of the homepage had a separate section for videos (see Lohlker 2016) now available on the YouTube channel.

The videos may be categorized as mission videos, including verbal and other attacks on the people distributing the Quran, conversions to Islam, and religious issues.

The mission videos try to attract the audience through the performance of the Salafi missionaries to a deeper study of the contents provided to the people passing by. The images of the video cause an effect of a shock transmitted through the images showing people sacrificing their time, their energy to the Salafi cause. By viewing these scenes, the audience gets attracted to the religiously imbued fundamentalist content brought close to him or her. Even if we don't have an 
esthetic shock, in this case, we may apply Benjamin's notion of the surreal to these videos (see below).

The videos have to submit to the protocols of the platform YouTube and the users are left with three options due to the structure of this platform (e.g., Vonderau 2009): 1) viewing, 2) viewing and embedding the video in self-produced Web content, or 3) commenting upon. Again, the freedom of the Web is easily discernible as a guided freedom.

The demarcation of boundaries is to be seen in several of the videos on religious issues criticizing non-acceptable way of living, acting, or believing defining what is not allowed among the members of the community. On the other hand behavior acceptable for the group is aptly described. The community building effect is reinforced by showing the public activities during the distribution of the Quran campaign.

All these effects are presented in a top-down way leaving to the viewer the reperformance of the performance seen on the screen, to make the digital code behind the digital icon (see below) visible in his life.

Other Salafi preachers are active online. A renowned Salafi preacher from Mauritania, Muhammad al-Hasan Ould al-Dedew (see Salem 2013, p. 93; and his official page at http://dedewnet.com/), established a YouTube channel in 2009.

As of November 2012, videos at this channel had been viewed nearly 500,000 times. The videos, most of them capturing remarks the Shaykh gave to live audiences, cover topics such as endowments [...], hajj, and various fatwas the Shaykh has issued. In many videos the Shaykh speaks in modern standard Arabic [...], rather than the Hassaniyya dialect that is widespread in Mauritania. This linguistic choice demonstrates his facility in the language of classical scholarship and makes his words intelligible to a broad Arab audience (Thurston 2012, p. 66).

The videos of this Salafi preacher are disseminated through several channels now, adapted to other languages using subtitles (e.g., German subtitles at the channel GermanyRida). Most of the videos present speeches, interviews, and the preacher participating in discussions. This way of distributing content is much more putting religion online than creating online creation a classification developed by Helland: "A distinction between online religion (where the religious activity actually occurred in the online environment) and religion online (where the medium was used as a tool to facilitate religious activity in the 'offline' world)" (see Helland 2012). Helland stated when studying

online activity associated with Tibetan Buddhism and the Tibetan Government in Exile, it became very clear that many people within this tradition do religion online by watching the Dalai Lama perform ritual activities and communicate information about their religion - of course many religious traditions function in this way. This activity is clearly "religion online" and the flow of information is absolutely from one-to-many. However, it 
is also a way of "doing" religion, much like sitting at the feet of the guru to receive a blessing or teachings, it is a powerful form of religious engagement and one that happens online now much more frequently with the development of new technologies that can broadcast HD and HP (high powered) sermons from charismatic religious leaders and teachers (Helland 2012).

Although publishing videos of Salafi preachers online may be seen as a deficient version of religion restricting the audience to listening and viewing these videos, it is another way of "doing" religion that leads to offline action published again online as in the case of diewahrereligion.

Other instances of creating an online context for "doing" religion, Salafi style, may easily be found, e.g., the YouTube channel salafmedia of the Somali preacher Maxamed cAbdi Umal (see also https:/www.facebook.com/salafmedia1) was set up in 2011 and has been viewed (January 15, 2016) 3,088,204 times. Most of the videos are filmed versions of his speeches, allowing the followers to attend the lectures virtually and thus watching the performance of the preacher, his way of "doing" religion.

Sometimes videos are used for a restaging of Salafi speakers who have died without being filmed. A prominent Salafi theoretician, Muhammad Nāsir ad-Dīn al-Albānī (died 1999) (see http://alalbany.me/), has published many audiocassettes (see http://alalbany.me/), some of them now presented as a video with or even without visual elements to accompany his verbal statements. This is a fine example for readily submitting to the new regime of visuality on the Web. A video biopic Sheikh Nasiruddeen al-Albani - the Albanian (other titles are available) gives a narration of al-Albānī thus giving the opportunity to construct a historically founded identity as a Salafi to the viewer. Another Salafi tradition is created when prominent Saudi scholars, al-Albānī, and others are presented together reciting the first chapter of the Quran (https://www.youtube.com/watch? $v=s p$ Cl52THKF0).

A Dailymotion channel presents a slightly different image of Salafism: amatouab. The usual videos of - all Arabs - preachers are available. A very special video shows the texts of the scholarly books on niqa $\bar{a} b$, the face-covering veil, following the reader line after line making it possible for the viewer to perform his own reading. Salafi couples are filmed as an example of family life with a song as background music sung by women. Other videos visualize the story told in a Hadith, a tradition of the deeds and sayings of the prophet, situated in a nostalgic bedouin setting. A capella songs are played with dynamic graphics as the visual element; a girls choir performs a song in praise of the Muslim veil. But videos of other songs are available not evidently conveying a Salafi message - unless the absence of the wife a family setting may be an indicator.

"Doing" religion may have a more public aspect when we look at videos showing, e.g., public gatherings of Tunisian Salafists with a group of men performing some martial arts moves in front of an audience acclaiming this per- 
formance. The Salafi speakers are seen waiting for their part of the event (https:// www.youtube.com/watch ? $\mathrm{v}=49 \mathrm{hsA5EzFX8)}$.

Videos are also used as a means to create a new brand of Salafism through the media, stressing the need to understand the agency of technology. In her case study of the YouTube channel salafimedia - not available at the time of writing Stadlbauer writes:

Salafimedia identifies as the most authentic and most modern Muslim community (ummah), as demonstrated in their most recent video posting, entitled The New Salafimedia Rebrand Video 2013: 4th Year Relaunch. Describing their new identity as rebranded and Salafism as a brand indexes marketing or business strategies - a new brand usually sells a new outlook. Furthermore, employing the metaphors of "rewriting the script" and "going back to the drawing board" further communicates the members" desires to reorganize and change their story, more so since they increasingly have to respond to accusations of radicalization by the UK government. Salfimedia becomes a platform for social action, and their beliefs become politicized.

The rebranding video has two parts: the first part presents action sequences and special effects that accompany important messages. For instance, the video begins with the image of a lion, later explained by "May Allah make us have the roar of a lion, with the heart of a lion". Text runs through the screen, urging the audience to "believe in it, live by it, be ready to die for it", where it refers to the promise of Allah, the call, or the revelation. In the transition to the second part, a wild black horse gallops over a dark, war-torn, post-apocalyptic world accompanied by lightning flashes, symbolizing both the destruction of a corrupt world and the renewal and power through Salafi Islam.

In the second part, four lecturers scold an imaginary Muslim audience about having forgotten the core message of the Prophet Muhammad from 1400 years ago. For special effects, superimposed animations of gunshots are fired through the screen and followed by explosions. The men project Salafism as "the truth and nothing but the truth" and they tell their followers that they are the best ummah. Especially prominent are the speakers' repeated calls to "enjoin the good and forbid the evil", highlighting the binary oppositions between the Salafis (the good) and the Western unbelievers or kufar (the evil). Only through a radical reorientation to the way of the salaf can the global ummah regain agency, strength, power, and victory. The video is an urgent wake-up call for misguided Muslims (Stadlbauer 2013).

This attempt to create third spaces (Hoover / Echchaibi 2014) demonstrates the potential of online videos, even if we do not share the worldview of the people running this video channel. It means the videos as a rebranding mechanism, Stadlbauer taking up the title of the video mentioned above, making possible the creation of new form of Salafism not seen before. All the videos discussed here 
hint at an audience interested in creating their own - Salafi - subjectivity submitting to the "undisciplined discipline" mentioned above.

An - again: under-researched - aspect of Salafi video activity online is the existence of many religious satellite TV channels. What makes the specific Salafi branding of these channels?

As a[n] [...] approach that places strong emphasis on literally mimicking the pious ancestors, looks are very important. Salafis view mannerisms of the Prophet, wearing a long beard for example, as a constant reminder of their commitment that will help avoid sin. These choices are reflected visually on Salafi stations: preachers wear long beards and the same type of clothing that the first generation of Islam would have worn, whereas preachers affiliated with the Brotherhood or who define themselves as non-Salafi wear less conspicuous robes or a suit and tie. The near total exclusion of women from the airwaves reflects Salafism's more rigid views on gender relations - a clear distinction from non-Salafi media. For example, on al-Resalah, a Kuwait-based non-Salafi satellite station, several female Egyptian ulema, who appear on-air wearing only the hijab, are listed as "stars of al-Reselah". [...] Another feature of Salafi networks is an unwillingness to give platforms to non-Salafi viewpoints: while other religious stations may give airtime to Salafi preachers they disagree with when given the chance, Salafis do not return the favor. (Field / Hamam 2009, p. 5)

But there are many other examples of the branding of a fundamentalist worldview, not a rebranding. One of them is Hindutva for the realm of Hinduism.

\section{Hindutva}

The Hindu-nationalist movement called Hindutva is a prominent case demonstrating the importance of Internet activities for fundamentalist movements. There are some discussions whether the concept of fundamentalism may be applied in this case since Hinduism is understood as a conceptually non-exclusive religion without fundamental texts as in the monotheist religions. Referring to Riesebrodt again, we may say Hindutva as an exclusive movement based on a selective relecture of a religious tradition shaping the subjectivity of its followers through a pious way of living based on the cultivation of a specific religious ethos. This allows us to describe Hindutva is a fundamentalist movement - much more political as in the first case study (e.g., Arvind 2002; Six 2006). Some authors make a distinction between religious Hindu fundamentalism and political Hindu fundamentalism (e.g., Ceming 2004).

A researcher argued, "the internet, in particular, seems to be the chosen medium for the Hindu nationalists working in technology to promote Hindutva", as they "help maintain over five hundred VHP Web sites through which to spread their messages about Hindutva, Hindu history, and Muslim-bashing" (Chopra 2006, p. 194). 
Two key principles have been identified that inform the audiovisual rhetoric of Hindu nationalism:

First, the video demonstrates that the Hindutva politics of representation is based on the technique of "intervisuality", whereby meaning emerges from the dynamic interplay of aesthetic and symbolic spaces and social practices. Second, Hindutva rhetoric relies on the use of "wish-images", through which imaginary "think-spaces" are opened that enable its ideologues to generate ideas of a crisis-ridden imagined community of Hindu nationals against the backdrop of a Golden Age and a utopian future (Brosius 2002, p. 265).

\section{Brosius continues:}

I have highlighted the Hindutva project to use video as an instrument for political transformation. It does so through the mimetic appropriation of already circulating narratives, iconographies and genres from the sphere of popular visual representation, and political and religious practices. New meaning is evolved when familiar imagery and narratives are situated in the new or altered context of dichotomies such as crisis and solution, exile/imprisonment and liberation, and stereotypes of "tolerant Hindus", "aggressive Muslims", the unresponsive state, and so on. Amidst this process of connectionmaking and -breaking in the videos, Hindutva spokesmen attempt to translate the abstract idea of nationalism into a "natural" object to be addressed through the intimate familial relationship of deshbhakti. Their dynamic practice of inter visuality not only connects different aesthetic realms but creates references to an alleged primordial, shared national past through language that is interpenetrated, via wish-images, with a desire for utopia.

However, the terrain of self-representation is a contested one, as Hindutva representatives have discrepant ideas about communication and the disciplining of imagined audiences (for example, regarding the priority of text versus image). Indoctrination via spectacle, entertainment, and "information", enshrined in the dense aesthetic and stylistic network of montage, magical realism, and mimesis, are the means through which the Hindutva ideologues attempted to "tickle" their audiences during the height of the Ayodhya campaign. The Hindutva rhetoric of people's empowerment is based on the power of desire, or temptation: While imagery, narratives and script create visions of a potent and "able body" of Hindu brethren, on the one hand, the viewers are "tamed" by metamorphosing them into disciplined, infantile devotee-machines and selfless martyrs on the battlefield of nationalism [...] (Brosius 2002, p. 292).

The creation of martyrs may be seen in the videos of the YouTube channel hindutvainus (https://www.youtube.com/user/hindutvainus/videos) showing training sessions of the Hindutva organization RSS demonstrating its "well-disciplined discipline" and the necessity to fight. Brosius analyzed the structure of Hindutva online activities from another angle in her study on HinduUnity.org: 
We can venture to say that the Web provides a place for the creation of a new form of intercultural and transnational iconography, even to those committed to militant nationalism and opposed to intercultural dialogue. In building this dynamic repertoire of images and visual rhetoric, symbols of the threatening Other are "magically fixed" through the strategies of appropriation, defamation, or humiliation. We are reminded here of a key text by Evelyn Kallen entitled "Hate on the Net" [...]. Kallen distinguishes three interconnected means of using the Web as a "hate-mongering" tool: An "invalidation myth" defines the target group (e.g. the Muslims) as inferior/dangerous; an "invalidation theory" provides the ideological framework, arguments and "evidence" to rhetorically attack minority groups; and finally as "a platform for organized community action", a hate website urges and provides the communicative means for the "threatened community" to take steps to aggressively counter or eliminate the purported threat.

The aim of HU is to create both an actual and an imagined virtual brotherhood of militant Hindus and to claim rights to representation over this homogenized community. The consumers of this vision are otherwise physically out of reach to each other and to the prime movers of HU (social encounters happen predominantly on the net; real world encounters within HU seem rare). The visitors to the HU site can then be seen as an audience responding to the facilitation of a communication platform, responding to projections of Hindus seen and shown as victims, judges, or soldiers. Through various performative strategies, the affective components of the possibility to participate in this world of victims, judges, vigilantes and soldiers, and the urge to "make an impact" on this world, are evoked. The tenor of all the articles and images available, on and through the HU homepage, is one of ongoing confrontation and crisis: Hindutva, for the makers and producers of $\mathrm{HU}$, is the organized, aggressive, cohesive articulation of what it is to be a Hindu today, and is the only way to protect Hindu identity against national and international threats. HU creates credibility, and thus authority, by entangling the visitor in a claustrophobic space, seemingly filled with countless details of "the evidence of the historical and ongoing humiliation, torture and abuse of Hindus". And having done so, it puts forward what it calls "justified" strategies to encounter the cause/s of this crisis.

Even though most of the images, rhetoric and ideological content put on display on a website like HinduUnity are not new, and can be traced back to the writings of Sangh Parivar ideologues such as Veer Savarkar or Golwalkar, it is the ways in which the images are presented and combined that constitutes a strange amalgam of virtual reality/actuality, or, as I indicated in the title of this article, surreality. I employ the term surrealism with some deliberation. I use it here in reference to two issues which I find are at stake in the Hindu Right's use of the internet: One is the conscious alignment of two or more different images, each drawn from different "real" locations or contexts within one composition, creating through the juxtaposition of two already familiar materials a strange feeling of augmented and renewed familiarity that causes a heightened, uncanny sense of reality. The second issue emerges from the idea of montage and pulls in cultural historian Walter Benjamin's work on media aesthetics and propaganda. Benjamin's notion of the surreal proposed that the effect of a shock transmitted through image consumption brings to a standstill the free flow of associations. The aesthetic shock freezes perception and at the same time heightens our senses; it creates an aura by means of which the necessary critical distance of the viewing subject succumbs to the concentrated transmission of ideologically imbued content. The magical condensation of 
meaning embodied in images brings the viewed object close to us, renders it as if it were tactile, and makes available to our desires and fears what otherwise remains abstract and distant. Fetishization (which pulls one closer to the object or feeling desired) and xenophobia (which repels and makes more distant the "other") are thus simultaneously central to the virtual surrealism of HinduUnity [...] (Brosius 2004, pp. 140 f.).

This surreality may be seen in a less elaborate form in the Salafi videos discussed before. Due to the aversion to pictorial representation in the Salafi varieties of Islam it has to be constructed as a series of speech acts. For Hindutva, it is important to notice the impact of the rhetorics and visual production will have on the individual activists who are to follow the ideals propagated in the videos being subjected to the effects of the media and only free to perform the message.

One aspect of Hindutva video practice is still to be mentioned. At the website sarvarkar.org dedicated to the ideologue of the movement V. D. Sarvarkar (id. 1966) has a video section. In this section are several videos starting with a clip of Sarvarkar himself and offering some visual documents and documentary films. We may read this as the construction of a history of the movement and its founder using videos as a means to build an identity on the foundational relecturer of the religious tradition. A very active Twitter account of the journal Hinduism Today (see https://twitter.com/HinduismToday) highlights another aspect of Hindutva online activity.

Turning to the performative aspect of religion online, we may look into a phenomenon that is specific for online Hinduism: the Hindu temples on the Web. Although these sites may not endorse the program of Hindutva, they are nevertheless a focus of Hindutva followers.

Analytically speaking, three "types" constitute the domain of Hindu temples on the Web: (1) the temple homepage, which functions as the online home for a physical temple; (2) the commercial puja site, which facilitates rituals services in prominent temples on behalf of their clients for a fee; and (3) the Hindu discourse site, which presents the temple as a virtual space for mediation, prayer and explication of Hindu religious discourse (Mallapragada 2010, p. 110).

The author argues

that Hindu temples sites demonstrate the emergence of what I call "desktop deity culture" constituted through the practices of digital darshan, online rituals, and virtual Hinduism. These Web practices, in turn, exemplify the "remediation" (Bolter and Gru$\sin$ ) of new media conceptualizations of digitality, network capital flows, hypertextuality and virtuality as they are articulated to ideas of the Hindu image, embodied ritual practice and the temporal and spatial logic of the temple as a sacred place (Mallapragada 2010, p. 111). 
These temple sites may be understood as "repurposing 'older' media forms such as photographs of deities, Hindu calendar art, the analog sacred texts and temple books, audio tapes of religious discourse through their textual and discursive practices of representing online temples" (ibid.). As such they fit into the category of performing religion online and can be appropriated by everybody participating as far as the structure of the site allows participation. Again these sites are dominated by the protocol or the code of the site. This domination through protocol is much more evident in another online practice not explored here: digital games. A first study on the first India-produced digital game Hanuman: Boy Warrior (see Zeiler 2014) has opened up the Asian sphere of gaming and religion. Hindutva online activities especially try to reach the US diaspora, another aspect not to be discussed here (see Therwath 2012).

\section{Repetitive Performance}

An added value of fundamentalist internet activity is the possibility to perform again and again the true message of god, the repetitive effect of internet videos, e. g., lends itself easily to a repetitive performance, staging and embodiment of the fundamentalist ethos and subjectivity or the protocol structuring fundamentalist subcultures and communities.

Another added value of Internet activity is the fact that persons acting as leaders of communal congregations act today as actors in front of an audience feeling as part of a performance blurring the distinction between producing and produced (see Lohlker 2016). So any fundamentalist actor understands himself or herself as performing the fundamental ethos of his or her group, not only reproducing it.

Is the Internet fundamentalist? Evidently not! But technological structures and technological practices of the self-lend itself can easily be used by fundamentalist individuals, groups, organizations, and networks. Boris Groy contributed to this discussion when speaking about "the digitized religion" and the role of videos (for a preliminary analysis see Lohlker 2016):

However $[\ldots]$, the new religious movements operate primarily through the Internet by means of digital and not mechanical reproduction. During the last decades, video has become the chosen medium of contemporary religious propaganda and is distributed through different TV channels, the Internet, commercial video stores, ${ }^{1}$ etc. This is especially true in the case of the most recent, most active, and even aggressive religious movements. [...] This use of the video as the major medium of self-presentation among

1 We may note the Eurocentric bias in not mentioning the role of audio-cassettes and radio in non-"Western" environments (see for a case study in Egypt Hirschkind 2006) (R.L.). 
different religious movements is a relatively new phenomenon. [...]

At this point, I would argue that the use of video as the principal medium by contemporary religious movements in intrinsic to the message of these movements. Neither is it external to the understanding of the religious, as such, as it underlies this use. This is not to suggest, following Marshall McLuhan, that here the medium is the message but rather, as I would argue, that the message has become the medium - a particular religious message has become the digital code.

Digital images have the propensity to generate, to multiply, and to distribute themselves almost anonymously through open fields of the contemporary means of communication. [...] digitalization seems to guarantee a literal reproduction of a text or image more effectively than any other known technique. Naturally, it is not so much the digital image itself as the image file, the digital data which remains identical through the process of its reproduction and distribution. However, the image file is not an image - the image file is invisible. The digital image is an effect of the visualization of the invisible digital data (Groys 2011, p. 27).

The digital image can be seen only being performed. By performing something it is always interpreted or even misused through interpretation. This hints at the fundamental fallacy of fundamentalism claiming to return to the original meaning by constructing a part of its religious tradition as the original version without being aware of its technique of interpretation. The immutability of the digital file does not guarantee the immutability of content since it has to be transformed into human practice - performed (see Lohlker 2016). "In this respect, the digital image functions as a Byzantine icon - as a visible representation of invisible digital data. The digital code seems to guarantee the identity of different images that function as visualization of this code" (Groys 2011, p. 29). And in this respect, we may understand videos on the Web as a paradigmatic representation of the fundamentalist belief in the immutability of the sources of religious traditions - affected by the same problems fundamentalisms has to meet in offline reality. But again: videos are not fundamentalist per se. If the structures of video production, dissemination, transformation and perception on the Web that lend itself to a fundamentalist use it is possible to imagine a non-fundamentalist video production. That is beyond the framework of this article.

To think about a new reflected practice of using the Internet is still to be done, be it in religious practices or any other form. We should remind ourselves of the problems of expressing the relation to a non-human reality in human language in an older communication system, oral and literal (see Giesecke 1992).

In the beginnings of research on religion and the Internet, there was a problem concerning the "textual character of so much computer-mediated communication. Can religious experience be embodied in words alone?" (Dawson 2006, p. 17) Now we are facing the problem of religious practice embodied in moving pictures on the screen to be reflected upon in the context of the technical objects (see Simondon 2014) in their interrelations to human actors. 


\section{References}

Achcar, Gilbert: The People Want. A Radical Exploration of the Arab Uprising. Berkeley / Los Angeles / London 2013.

Asad, Talal: "Thinking about Religion, Belief, and Politics", in: Orsi, Robert A. (ed.): The Cambridge Companion to Religious Studies. Cambridge et al. 2012, pp. 36-57.

Bellar, Wendy et al.: "Reading Religion in Internet Memes", in: Journal of Religion, Media \& Digital Culture (2.2) 2013, available at: https://www.jrmdc.com/journal/ar ticle/view/13 [15.01.2016].

Brosius, Christiane: "Of Nasty Pictures and 'Nice Guys'. The surreality of Online Hindutva”, in: Sarai Reader 04: Crisis/Media 2004, pp. 139-151.

Brosius, Christiane: "Hindutva intervisuality: Videos and the politics of representation", in: Contibutions to Indian Sociology (36.1,2) 2002, pp. 265-295.

Campbell, Heidi A.: "Introduction: The Rise of the Study of Digital Religion", in: id.: Digital Religion: Understanding Religious Practice in New Media Worlds. London / New York 2013, pp. 1-21.

Ceming, Katharina: Hinduismus: Auf dem Weg vom Universalismus zum Fundamentalismus?, available at: http://them.polylog.org/5/ack-de.htm [15.01.2015] (and in polylog (12) 2004).

Ceylan, Rauf / Jokisch, Benjamin (eds.): Salafismus in Deutschland. Entstehung, Radikalisierung und Prävention. Frankfurt a. M. 2014.

Chopra, Rohit: "Global primordialities: virtual identity politics in online Hindutva and online Dalit discourse", in: New Media \& Society (8.2) 2006, pp. 187-206.

Dabashi, Hamid: The Arab Spring: The End of Postcolonialism. London 2012.

Dawson, Lorne L.: "The Mediation of Religious Experience in Cyberspace”, in: Højsgaard, Morten T. / Warburg, Margit (eds.): Religion and Cyberspace. London / New York 2005, pp. 15-37.

Field, Nathan / Hamam, Ahmed: "Salafi satellite TV in Egypt", in: Arab Media \& Society Spring 2009, available at: http://www.arabmediasociety.com/articles/downloads/ 20090506151157_AMS8_Field_and_Hamam.pdf [15.01.2016].

Galloway, Alexander: Protocol: How Control Exists after Decentralization. Cambridge, Mass. / London 2004.

Giesecke, Michael: Sinnenwandel, Sprachwandel, Kulturwandel: Studien zur Vorgeschichte der Informationsgesellschaft. Frankfurt a. M. 1992.

Golbeck, Jennifer: Introduction to Social Media Investigation: A Hands-on Approach. Amsterdam et al. 2015.

Golbeck, Jennifer: Analyzing the Social Web. Amsterdam et al. 2013.

Groys, Boris: "Religion in the Age of Digital Reproduction", in: Groys, Boris / Weibel, Peter (eds.): Medium Religion: Faith. Geopolitics. Art. Köln 2011.

Harman, Graham: Prince of Networks: Bruno Latour and Metaphysics. Melbourne 2009. Helland, Christopher: Christopher Helland on Online Religion and Religion Online. Posted May 14, 2012, available at: http://digitalreligion.tamu.edu/blog/mon-0514 2012-1132/scholar\% E2\% 80\% 99s-top-5-christopher-helland-online-religion-and-reli gion-online [15.01.2016].

Hirschkind, Charles: The Ethical Soundscape: Cassette Sermons and Islamic Counterpublic. New York / Chichester 2006. 
Hoover, Stewart M. / Echchaibi, Nabil: The „Third Spaces“ of Digital Religion. 2014, available at: http://cmrc.colorado.edu/wp-content/uploads/2015/05/Third-Spaces-ofDigital-Religion-Draft.pdf [15.01.2016].

Houtman, Dick / Aupers, Stef: "Religions of Modernity: Relocating the Sacred to the Self and the Digital", in: Aupers, Stef / Houtman, Dick (eds.): Religions of Modernity: Relocating the Sacred to the Self and the Digital. Leiden / Boston 2010, pp. 1-29.

Latour, Bruno: Reassembling the Social: An Introduction to Actor-Network-Theory. Oxford et al. 2005.

Lohlker, Rüdiger: "Performativität des Religiösen:(Neo-)Fundamentalistische Videos", in: Appel, Kurt / Guanzini, Isabella (eds.): Europa mit oder ohne Religion? II: Der Beitrag der Religion zum gegenwärtigen und künftigen Europa. Göttingen 2016, pp. 131-148.

Lovink, Geert: Zero Comments. Blogging and Critical Internet Culture. New York / London 2008.

Mallapragada, Madhavi: "Desktop deities: Hindu temples, online cultures and the politics of remediation", in: South Asian Popular Culture (8.2) 2010, pp. 109-121.

Mahmood, Saba: Politics of Piety: The Islamic Revival and the Feminist Subject. Princeton / Oxford 2005.

Najar, Sihem: Les réseaux sociaux sur Internet à l'heure des transitions démocratiques. Tunis / Paris 2013.

Reichert, Ramón: "Selfie Culture: Kollektives Bildhandeln 2.0”, in: Pop-Zeitschrift (7) 2015, pp. 86-96.

Reichert, Ramón: Amateure im Netz: Selbstmanagement und Wissenstechnik im Web 2.0. Bielefeld 2008.

Rheingold, Howard: The Virtual Community. Homesteading at the Electronic Frontier. Cambridge, Mass. / London 1993.

Riesebrodt, Martin: "Was ist 'religiöser Fundamentalismus'?", in: Six, Clemens et al. (eds.): Religiöser Fundamentalismus: Vom Kolonialismus zur Globalisierung. Innsbruck 2005, pp. 13-32.

Said, Behnam T. / Fouad, Hazim (eds.): Salafismus: Auf der Suche nach dem wahren Islam. Freiburg i. Br. 2014.

Salem, Zekeria Ould Ahmed: Prêcher dans le désert. Islam politique et changement social en Mauritanie. Paris 2013.

Schneiders, Thorsten Gerald (ed.): Salafismus in Deutschland: Ursprünge und Gefahren einer islamisch-fundamentalistischen Bewegung. Bielefeld 2014.

Sharma, Arvind: "On Hindu, Hindustan, Hinduism and Hindutva”, in: Numen (49.1) 2002, pp. 1-36.

Simondon, Gilbert: Sur la technique (1953-1983). Paris 2014.

Simondon, Gilbert: "Mentalité technique", in: Revue philosophique de la France et de l'étranger (196.3) 2006, pp. 343-357.

Six, Clemens: Hindi - Hindu - Hindustan: Politik und Religion im modernen Indien. Wien 2006.

Stadlbauer, Susanne: Salafism on YouTube: Rebranding, Reforming or Reviving Islam?, available at: https://thirdspacesblog.wordpress.com/2013/03/13/salafism-on-youtuberebranding-reforming-or-reviving-islam/ [15.01.2016]. 
Therwath, Ingrid: "Cyber-hindutva: Hindu nationalism, the diaspora and the Web", in: Social Science Information (51.4), pp. 551-577.

Thurston, Alex: Shaykh Muhammad al-Hasan al-Dedew (b. 1963), a Salafi Scholar in Contemporary Mauritania, available at: http://www.cci.uct.ac.za/usr/cci/publications/ aria/download_issues/2012/Alex\%20Thurston.pdf [15.01.2016].

Tibi, Bassam: Der Islam und das Problem der kulturellen Bewältigung sozialen Wandels. Frankfurt a. M. 1985.

Vonderau, Patrick / Snickers, Pelle: The YouTube Reader. Stockholm 2009.

Zeiler, Xenia: "The Global Mediazation of Hinduism Through Digital Games: Representation Versus Simulation in Hanuman: Boy Warrior", in: Campbell, Heidi A. I Grieve, Gregory P. (eds.): Playing with Religion in Digital Games. Bloomington / Indianopolis 2014, pp. 66-87. 